\title{
Big is beautiful for survival of higher education in Australia
}

Sydney

FORCED amalgamations for tertiary institutions with fewer than 2,000 students is the most contentious element of new Australian government policy on higher education announced at the end of last month by Mr John Dawkins, Minister for Education, Employment and Training. The policy gives effect to most of the reforms suggested last December (see Nature 330, 592; 1987).

The central element of the policy is the establishment of a 'unified national

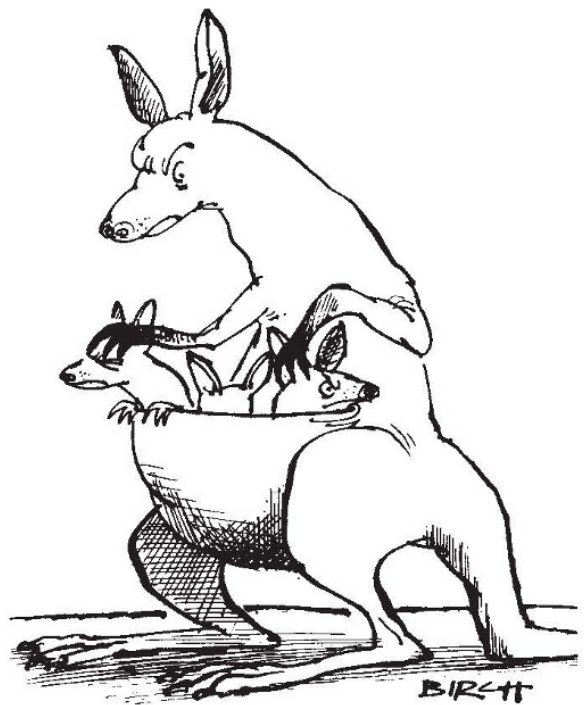

system' for higher education. In order to join, an institution will have to prepare an 'institutional profile' which sets out its objectives and strategy for teaching and research as well as how it is addressing national priorities as defined by the government. Funding will be based on the institutional profile as well as objective statistical measures of performance compiled by the government. From 1989, funding for institutions in the unified national system will be a single operating grant which will replace present separate general recurrent, equipment, minor works and special research grants.

Institutions choosing not to join the unified system will be funded for teaching only, receiving nothing for growth or research. Institutions with fewer than 2,000 students, of whom there are at present 21 , will not be allowed to join the unified national system. Pressure will also be put on institutions with between 2,000 and 5,000 students to amalgamate. The minimum number of students is 5,000 , at which the government believes an institution will be able to deliver a comprehensive range of courses as well as being able effectively to involve itself in research in some specialized areas.

Private institutions such as the Bond University will not receive any government support, nor will their students be eligible for study benefits. Staff will, however, be able to compete for research grants from the Australian Research Council (ARC). Money for research will be transferred from operating grants to the ARC in stages, until the ARC has an extra A \$65 million in 1991.

The policy statement emphasizes the government's desire to improve management practices in higher education. Dawkins says that it is impossible for some university senates and college councils with up to 50 members to operate efficiently. He says a more appropriate size would be $10-15$, in line with the size of boards in large private organizations.

Charles Morgan

\section{UK universities turning more and more to private funding}

\section{London}

UNIVERSITIES in Britain are relying increasingly on private rather than public funding. Statistics published this month by the Universities Statistical Record, which detail income and expenditure in 1986-87, show that the proportion of university funding from central government grants fell to 55 per cent, compared with 57 per cent and 59 per cent in the previous 2 years and 75 per cent 10 years ago.

Last year's grant of $£ 1,400$ million was a 4 per cent increase on the previous year. And the total income of universities increased by 8 per cent to almost $£ 2,500$ million. But the underlying trend is an increase in the proportion of university income earned from research contracts and services, a trend that the government is encouraging. Last year, the funding generated in this way rose by 18 per cent, almost $£ 100$ million, to $£ 630$ million.

There was an increase in funding of 28 per cent from charities, of 22 per cent from overseas organizations, of 16 per cent

\section{Spanish Cabinet in scien Barcelona}

IN a cabinet reshuffle, Mr José María Maravall has been replaced as Spanish Minister of Education and Science by $\mathbf{M r}$ Javier Solana, former Minister of Culture, who will take over at a delicate time for education and science in Spain.

Maravall, Minister of Education and Science since the first socialist government in 1982, has been responsible for important reforms in primary and secondary schools, in universities (the Law for University Reform) and in science (the Law of Science and the National Plan for Research).

Solana, a physicist with experience in from British industry and of 14 per cent from the research councils.

Income from fees also rose, due largely to the increase in fees charged to overseas students. Fee income rose by nine per cent from the previous year, $£ 26$ million to $£ 330$ million, the same level as five years ago; since then income from full-time students paying home fees has fallen by almost one-third.

Universities' expenditure increased by 6 per cent to $£ 1,850$ million, bringing the increase over the past five years to almost one third. Last year, 68 per cent of general funds went on salaries and wages, an increase of 7 per cent on the previous year, and of almost one-third over the past five years. The largest rise (54 per cent) was for academic-related staff such as administrators and computer staff, compared with 20 per cent for technical staff.

Over the past five years, student-staff ratios have increased in most departments, particularly in clinical subjects, because reductions in full-time staff have been substantially greater, says the report, than the changes in student numbers. Last year there were about 55,000 full-time staff and 3,500 part-time academic and related staff, a 3 per cent rise over the previous year. That increase was due to an increase of 9 per cent in the number of staff not paid from university funds. Those staff now constitute one-third of all fulltime academic staff, compared with 23 per cent 5 years ago. There was no increase in the number of full-time teaching and research staff paid from general funds. Of staff not paid from general funds, 38 per cent are financed by the research councils, 21 per cent by other government departments and 10 per cent by industry.

Christine McGourty 